\title{
Prevalence of human immunodeficiency virus in the inmates of district Jail Quetta, Balochistan
}

\author{
Niamatullah Kakar ${ }^{1}$, Tauseef Muhammad Asmat ${ }^{1 *}$, Ferhat Abbas ${ }^{1}$, \\ Habib Ur-Rehman ${ }^{2}$, Asmatullah Kakar ${ }^{3}$, Kalimullah Khan ${ }^{4}$ and Farah \\ Sabeen Bugti ${ }^{1}$
}

1. Center for Advanced studies in Vaccinology and Biotechnology (CASVAB), University of Balochistan, Quetta-

Pakistan

2. Department of Microbiology, University of Balochistan, Quetta-Pakistan

3. Faculty of Pharmacy, University of Balochistan, Quetta-Pakistan

4. Department of Microbiology, Kohat University of Science and Technology, Kohat-Pakistan

*Corresponding author's email: tauseefcasvab@gmail.com

Citation

Niamatullah Kakar, Tauseef Muhammad Asmat, Ferhat Abbas, Habib Ur-Rehman, Asmatullah Kakar, Kalimullah Khan and Farah Sabeen Bugti. Prevalence of human immunodeficiency virus in the inmates of district Jail Quetta, Balochistan. Pure and Applied Biology. Vol. 6, Issue 1, pp164-170. http://dx.doi.org/10.19045/bspab.2017.60010

Received: 30/11/2016 Revised: 17/01/2017 Accepted: 29/01/2017

Online First: 02/02/2017

\section{Abstract}

The human immunodeficiency virus (HIV) infection commonly known as acquired immunodeficiency syndrome (AIDS) is caused by a lentivirus (HIV). The prevalence of HIV is well documented globally but such statistics are sparse from Pakistan and there has been no such data from Balochistan at all. The current study was designed and conducted to assess the seroprevalence of HIV amongst jail inmates in Quetta, Pakistan. A total of 200 out of 350 male prisoners were selected randomly for HIV testing. The prisoners included in the study, voluntarily completed a risk-factor questionnaire and blood samples were provided for unlinked anonymous testing for the presence of antibodies to HIV. All the subjects were above 18 years of age. Informed consent was obtained. We measured sero-prevalence and assessed the risk factors for HIV by using Abbot Determine ${ }^{\circledR}$ rapid screening kit (specificity 100\%). Reactive specimens were further assessed for anti-HIV antibodies by enzyme linked immuno sorbent assay (ELISA). Of total 200 prisoners, $0.5 \%$ of the prisoners were found positive for HIV antibodies using ELISA which is equal to the HIV prevalence in world population. But being an Islamic country where extramarital sex and drugs are illegal and banned the resulted HIV prevalence in inmates of the District Jail Quetta, Pakistan is alarming and there is need to educate the prisoners to minimize the risk factors associated with HIV transmission.

Keywords: Seroprevalence; Jail inmates; Human immunodeficiency virus (HIV); Enzyme linked immunosorbent assay (ELISA); Quetta; Pakistan

\section{Introduction}

Despite the fact that the number of Immunodeficiency Virus (HIV) infections has decreased worldwide, this trend is not uniform and varies significantly from region to region [1]. Due to this reason, HIV pandemic continues to remain a major health problem throughout the world. In an annual 
report on HIV/AIDS of the World Health Organization (WHO) approximately 2.7 million new cases were identified with HIV in 2010 and this number was about $15 \%$ less than HIV infection in 2001 (3.3 million infected), which was less than HIV infected people in 1997 (3.4 million affected) [2].

However, in the low-income countries where HIV/AIDS remains an epidemic, one in every five adults is infected with HIV. Some African's countries are at the worst end of HIV/AIDS epidemic and over 22.9 million people are infected with HIV/AIDS. In terms of prevalence, countries such as Afghanistan and Saudi Arabia are reported to have the lowest prevalence $(0.01 \%$ of total population) rate amongst the reported nations [2-4].

In Indonesia, Pakistan and Vietnam the number of HIV/AIDS infected people or the rate of incidence of HIV/AIDS infection has been increased $[5,6]$ but there is an immense variation between and within these countries. HIV is not currently an overriding epidemic in Pakistan, because Pakistan is an Islamic state and the majority of the population is Muslim, where by law and religion the extramarital sex is banned. However, the number of HIV/AIDS cases has increased in the recent years [7]. According to the figures of National AIDS Control Program (NACP) of Pakistan, over 4,000 HIV cases have been reported since 1986. Moreover, numbers of HIV/AIDS positive case are even more according to the WHO, United Nations International children's emergency Fund (UNICEF) and United Nations Program on HIV/AIDS [7]. High risk groups comprising, injecting drug users (IDUs), transgender sex workers (TSWs), commercial sex workers (CSW) and prisoners have taken the hold of HIV epidemic in Pakistan [8].

Despite of low HIV prevalence in adults, social and economic conditions including poverty, lack of education, and high degree of risk behaviors among the IDUs, sex workers and prisoners have more HIV cases in Pakistan [9]. HIV prevalence in IDUs has greatly elevated from $10.8 \%$ to $21 \%$ from 2005-2008 in the country [7].

Apart from the well-established HIV risk groups, threat of HIV spread among the jail inmates has emerged as a serious issue. Prevalence of HIV infection within prison inmates is much higher (10-25\%) compared to the world general population $(0.5 \%)$ [10]. HIV prevalence in the inmates of sub-Sahara Africans has been estimated up to 50 times more than non-prison population [11].

A rapid HIV transmission was reported in the prisons of Scotland [12]. Another outbreak occurred in Lithuania prison in 2002 where at random test by the state run AIDS Center, identified 263 jail inmates at prison were reactive for HIV antibodies [13].

The prevalence of HIV infection has been reported in different jails of Pakistan. For example, in Sind province, out of 4987 prisoners in different jails, the distribution of HIV positive cases were 32 from Karachi Jails, 07 from Sukkur Jails, 03 from Hyderabad Jails, 04 from Larkana Jails and 02 from Shikarpur Jails [14]. In Punjab province of Pakistan, 1000 male prisoners of different jails were screened for HIV and 44 prisoners $(4.4 \%)$ were found positive for HIV [15].

Balochistan is the largest province of the country and Quetta is its capital and serves as the only metropolitan city of the province. Here people belong to different castes with many refugees who migrated from war affected country of Afghanistan during the early 1980s and 1990s [16].

No Study has been conducted yet to report the HIV prevalence and risk factors in the Jail inmates of Balochistan province of Pakistan. Therefore, the aim of this study was to provide the preliminary information about HIV prevalence and its risk factors 
amongst Jail inmates of Quetta, Balochistan. This study will be useful to formulate the public health strategy for the prevention of risk factors associated with spreading of HIV in prisons of Balochistan.

\section{Materials and methods}

\section{Study location}

This study analyzed HIV prevalence and associated high risk behaviors connected with the transmission of HIV amongst the adult males incarcerated in the largest prison of the city, the Central Jail, Hudda, situated in Quetta, the capital of Balochistan province of Pakistan. Quetta has a population of about 896,090 people, according to 2001 censuses.

\section{Study design}

This study was designed to determine the prevalence and associated risks of HIV among the inmates of the Central Jail Quetta. For this purpose, a structured questionnaire consisting of 12 variables was designed to collect the demographic data and related clinical information regarding age, weight, educational level, profession, marital status, occupation, duration of incarceration, extramarital sex before incarceration, Injected Drug Addict, homosexuality, sharing of syringes, sharing razors and Blood transfusion.

The total incarcerated population at the time of this study was approximately $(n=350)$ with different duration of incarceration. Informed consents were obtained before filling the questionnaire and those who did not consent to participate were excluded from the study. A total of 200 HIV suspected adult male prisoners out of 350 , between 18-60 years, were tested for HIV in the District Central Jail of Quetta, Balochistan.

\section{Data collection}

A team of Medical Doctor, a laboratory technician and phlebotomist was organized to collect the blood samples. Blood samples (about 5ml) were collected aseptically according to standard protocols.

All collected sample sera were tested in Biosafety Level III (BSL III) laboratory at Provincial Reference Laboratory (PRL), Fatima Jinnah General \& chest Hospital, a tertiary care hospital in the city of Quetta, Balochistan to detect the HIV antibodies.

HIV antibodies' testing was done using rapid Immuno-chromatographic (ICT) Abbot Determine ${ }^{\circledR}$ rapid screening kit. Reactive specimens were assayed by immunosorbent assay (ELISA) strip reader, Read well DOT diagnostic according enzyme linked to the manufacturer instruction. Funding restrictions did not allow to conduct the molecular base study.

\section{Results}

A total of 200 inmates were included in the study. Table 1 outlines the basic Sociodemographic characteristics of the inmates. All the participating prisoners were male with the mean age of 39 (18- 60 years). Sixty eight per cent of prisoners were having weight of $>60 \mathrm{~kg}$ and rests of the prisoners were less than $60 \mathrm{~kg}$. $60 \%$ were not married, $89.5 \%$ had no extramarital sex history and homosexuality was reported to be $2.5 \%$ (Table 1). More than half of the prisoners $69 \%(n=138)$ were illiterate and literacy rate was only $31 \%(n=62)$. Before the beginning of their current confinement, $34(17 \%)$ were unemployed, 39 (19.5\%) were employed, and the number of prisoners working on daily wages were 127 (63.5\%) (Table 1). The number of prisoners with more than 4 years of incarceration were 15 $(7.5 \%), 43(21.5 \%)$ were of the duration of 2-3 years, $68(34 \%)$ were of 1-2 years and $74(37 \%)$ were of the period $<1$ year.

Altogether, $27(13.5 \%)$ prisoners were sharing needles and $20(10 \%)$ prisoners were engaged in sharing of razors during incarceration as well as before incarceration; while other 180 (90\%) prisoners did not have such habit (Table 1). 
When tested for HIV Positivity, among 200 anti HIV antibodies (Table 2).

prisoners, one person $(0.5 \%)$ was having

Table 1. Sociodemographic characteristics of inmates tested for HIV

\begin{tabular}{|c|c|c|c|}
\hline S. No. & Variables & No of Prisoners & Percentage (\%) \\
\hline 1 & \multicolumn{3}{|l|}{ Age (years) } \\
\hline & $18-30$ & 137 & $68.5 \%$ \\
\hline & $31-40$ & 32 & $16 \%$ \\
\hline & $41-50$ & 21 & $10.5 \%$ \\
\hline & $>50$ & 10 & $5.0 \%$ \\
\hline 2 & \multicolumn{3}{|l|}{ Weight (Kg) } \\
\hline & $50-60$ & 64 & $32 \%$ \\
\hline & $>60$ & 136 & $68 \%$ \\
\hline 3 & \multicolumn{3}{|l|}{ Education } \\
\hline & Illiterate & 138 & $69 \%$ \\
\hline & Literate & 62 & $31 \%$ \\
\hline 4 & \multicolumn{3}{|l|}{ Previous Occupation } \\
\hline & Employed & 39 & $19.5 \%$ \\
\hline & Unemployed & 34 & $17 \%$ \\
\hline & On Daily wages & 127 & $63.5 \%$ \\
\hline 5 & \multicolumn{3}{|l|}{ Duration of Incarceration } \\
\hline & $<1$ year & 74 & $37 \%$ \\
\hline & $1-2$ years & 68 & $34 \%$ \\
\hline & $2-3$ years & 43 & $21.5 \%$ \\
\hline & $>4$ years & 15 & $7.5 \%$ \\
\hline 6 & \multicolumn{3}{|l|}{ Current Smoking Status } \\
\hline & Non-Smoker & 58 & $29 \%$ \\
\hline & 1-5 cigarettes/day & 44 & $22 \%$ \\
\hline & 6-10 cigarettes/day & 18 & $9 \%$ \\
\hline & $>10$ cigarettes/day & 80 & $40 \%$ \\
\hline 7 & \multicolumn{3}{|l|}{ Marital status } \\
\hline & Married & 80 & $40 \%$ \\
\hline & Un-Married & 120 & $60 \%$ \\
\hline 8 & \multicolumn{3}{|l|}{ Drug Addict } \\
\hline & Yes & 35 & $17.5 \%$ \\
\hline & No & 165 & $82.5 \%$ \\
\hline 9 & \multicolumn{3}{|l|}{ Extramarital sex ever } \\
\hline & Yes & 21 & $10.5 \%$ \\
\hline & No & 179 & $89.5 \%$ \\
\hline 10 & \multicolumn{3}{|l|}{ Homosexuality ever } \\
\hline & Yes & 5 & $2.5 \%$ \\
\hline & No & 195 & $97.5 \%$ \\
\hline 11 & \multicolumn{3}{|l|}{ Share needles } \\
\hline & Yes & 27 & $13.5 \%$ \\
\hline & No & 173 & $86.5 \%$ \\
\hline 12 & \multicolumn{3}{|l|}{ Razors sharing } \\
\hline & Yes & 20 & $10 \%$ \\
\hline & No & 180 & $90 \%$ \\
\hline
\end{tabular}


Table 2. Prevalence of HIV in district Jail Quetta

\begin{tabular}{|l|c|c|c|}
\hline Test & Sample size (n) & No of positive cases & No of Negative cases \\
\hline HIV & 200 & $1(0.5 \%)$ & $199(99.5 \%)$ \\
\hline
\end{tabular}

HIV: Human immunodeficiency virus

\section{Discussion}

Worldwide the number of HIV/AIDS new infections has decreased but still it is a serious global health hazard. World Health Organization (WHO) reported that nearly 2.7 million new cases of HIV were reported in 2010 and it was $15 \%$ less than WHO figures of HIV newly infected people in 2001 [17]. World Health Organization considered the HIV epidemic as pandemic [18]. Prevalence of blood born and sexually transmitted infections was reported significantly higher in prisoners as compared to the general population worldwide [18-23]. This high prevalence is largely attributed to the illegal IDUs and sex. These sexually transmitted infections (STIs) lead to huge health and economic burden for developing countries [24].

This study demonstrated that 21 (10.5\%) and $5(2.5 \%)$ prisoners were involved in extra marital sex and MSM respectively and it may be alarming as $67 \%$ of new HIV/AIDS infections was contributed by MSM in United States (HIV/AIDS Surveillance Report, 2014). Most of the Prisoners have had acquire HIV/AIDS before being locked, the high prevalence of HIV infection in prison is mostly attributes with inject-able drug [25].

In Pakistan, about 100,000 people are injecting drug users (IDU) and exposed to a major HIV infection acquiring mode. Blood-borne infections can be transmitted by sharing of razors for shaving, and the improper sterilization or re-use of medical or dental instruments [26]. Our study revealed that $27(13.5 \%)$ cases were involved in sharing of needles; furthermore, it was also demonstrated that 20(10\%) prisoners were engaged in sharing of razor during incarceration as well as before incarceration. Both in developed and developing countries overcrowding in prisons, remain a big problem and is a key causative factor for transmitting diseases such as AIDS, hepatitis and tuberculosis [27].

HIV prevalence has been reported in other provinces of Pakistan including Sindh and Punjab. Prevalence of HIV in different jails (Karachi, Hyderabad, Sukkur, Khairpur and Shikarpur) of Sindh province was reported to be1\% [28, 29], whereas $4.4 \%$ of HIV positive cases were reported in different jail prisoners of the Punjab province of Pakistan $[15,30]$.

In this study, we also found prevalence of HIV positive cases in the jail community of Quetta. The prevalence of HIV positive in this community was $0.5 \%$ which is equal to prevalence of HIV in world population. However this infection was significantly lower than that reported from other prisons of the Pakistan and world such as United State $6.6 \%$, Italy $7.5 \%$, Ghana $19.2 \%$ and South Africa 41.4\% [18].

\section{Conclusions and recommendations}

Despite of low prevalence of HIV compared to other prisons of Pakistan, it is important to plan future strategies to prevent its possible spread to other prisoners and jails of the province and subsequently in the country.

We strongly recommend the following:

1. Further research is needed to determine the extent of HIV infection and the occurrence of co-infections in other jails of the Balochistan province.

2. Introduction of comprehensive preventive measures and data management of HIV. 


\section{Authors' contributions}

Conceived and designed the experiments: $\mathrm{N}$ Kakar, TM Asmat \& F Abbas, Performed the experiments: N Kakar, HU Rehman \& A Kakar, Analyzed the data: N Kakar, TM Asmat \& F Abbas, Contributed reagents/ materials/ analysis tools: K Khan \& FS Bugti, Wrote the paper: N Kakar \& TM Asmat.

\section{References}

1. Jaquet A, Wandeler $\mathrm{G} \&$ Tine $\mathrm{J}$ et al (2016). HIV infection, viral hepatitis and liver fibrosis among prison inmates in West Africa. BMC Infect Dis 16: 241.

2. Worldwide AIDS \& HIV Statistics. http://www.avert.org/worldstats.htm. (2009, Retrieved 26 January 2011).

3. Routy JP, Psomas C, Soriano V, Philibert $\mathrm{P}$, Tissot-Dupont $\mathrm{H}$ \& Lafeuillade A (2016). Highlights from the 2016 International Symposium on HIV \& Emerging Infectious Diseases (ISHEID). J Virus Erad 2016 Jul; 2(3): 187-192.

4. Central Intelligence Agency: HIV/AIDS adult prevalence rate (2011).

5. Rao PJ, Mboi N, Phoolcharoen W, Sarkar S \& Carael M (2010). AIDS in Asia amid competing priorities: a review of national responses to HIV. AIDS. 24: 41-48.

6. UNAIDS: AIDS Epidemic update (2007). http://data.unaids.org/pub/epislides/2007 /2007_epiupdate_en.pdf.

7. UNAIDS: Lack of resources could undermine gains made in the HIV response in Pakistan (2010).

8. UNGASS: Pakistan report (2007). http://data.unaids.org/pub/Report/2008/p akistan_2008_country_progress_repo rt_en.pdf.

http://www.unaids.org/en/resources/pres scentre/featurestories/2010/february/2 0100205pakistan/.

9. UNAIDS: Report on the global AIDS epidemic

(2008).
http://data.unaids.org/pub/GlobalReport/ 2008/jc1511_gr08_executivesummary_e n.pdf.

10. Burattini MN, Massad E, Rozman M, Azevedo R \& Carvalho H (2000). Correlation between HIV and $\mathrm{HCV}$ in Brazilian Prisoners: Evidence for Parenteral Transmission inside Prison. Rev Saude Publica 34: 431-6.

11. United Nations Office on Drugs and Crime, UNAIDS: HIV and Prisons in sub- Saharan Africa (2008). http://www.unodc.org/documents/hivaids/Africa\%20HIV_Prison_Paper_Oct23-07-en.pdf.

12. Buavirat A, Page-Shafer K, Van Griensven GJ, Mandel JS, Evans J, Chuaratanaphonq J, Chiamwononqpat S, Sacks R \& Mosa A (2003). Risk of prevalent HIV infection associated with incarceration among injecting drug users in Bangkok, Thailand: case-control study. $\quad B M J$ 8:326. https://www.cia.gov/library/publications /the-world-factbook.

13. Dapkus L (2002). Prison's rate of HIV frightens a nation. Associated Press p. 29.

14. Salman S, Arshad M \& Syed QA (2009). Prevalence of HIV/AIDS among jail inmates in Sindh. J Pak Med 59: 111-2.

15. Daniela S (2011). Risk assessment of $\mathrm{HCV}$ and HIV infections among prisoners in Punjab, Pakistan. Library 1450.

16. Federal Bureau of Statistics, Government of Pakistan. Population, Area and Density by Region/Province 1998. Retrieved 2009.

17. UNAIDS: World AIDS Day Report (2011).

http://www.unaids.org/en/media/unaids/ contentassets/documents/unaidspublicati on/.

18. Nafees M, Qasim A, Jafferi G, Anwar MS \& Muazzam M (2011). HIV 
infection, $\mathrm{HIV} / \mathrm{HCV}$ and $\mathrm{HIV} / \mathrm{HBV}$ coinfections among jail inmates of Lahore. Pak J Med Sci 27: 837-841.

19. McMillan A (1988). HIV in prisons. BMJ 297: 873-874.

20. Mutter RC, Grimes RM \& Labarthe D (1994). Evidence of intra prison spread of HIV infection. Arch Intern Med 154: 793-795.

21. Taylor A, Goldberg D, Emslie J, Wrench J Gruer L, Cameron S, Black J, Davis B, McGregor J \& Follett E (1995). Outbreak of HIV infection in a Scottish prison. BMJ 310: 289-292.

22. Spaulding A, Stephenson B, Macalino G, William R, Clarke JG \& Flanigan TP (2002). Human immunodeficiency virus in correctional facilities a review. Clin Infect Dis 35: 305-312.

23. Adjei AA, Armah HB, Gbagbo F, Ampofo WK, Quaye IK, Hesse IF \& Mehsah G (2006). Prevalence of human immunodeficiency virus, hepatitis B virus, hepatitis $\mathrm{C}$ virus and syphilis among prison inmates and officers at Nsawam and Accra, Ghana. J Med Microbiol 55: 593-597.

24. Rosen DL, Schoenbach VJ, Wohl DA, White BL, Stewart PW \& Golin CE (2009). Characteristics and Behaviors Associated with HIV Infection among Inmates in the North Carolina prison
System. Am J Public Health 99: 11231130.

25. Pontali E \& Ferrari F (2008). Prevalence of Hepatitits B virus and /or Hepatitis C virus co-infections in prisoners infected with the Human Immunodeficiency Virus. Int J Prisoner Health 4: 77-82.

26. Jürgens R (2011). Nowak M and Day M. HIV and incarceration: prisons and detention. J Int AIDS 14: 26.

27. Andrew AA, Henry BA, Foster G, Ampofo WK, Boamah I, Adu-Gyamfi C, Asare I, Hesse IF \& Mensah G (2008). Correlates of HIV, HBV, HCV and syphilis infections among prison inmates and officers in Ghana: A national multicenter study. $B M C$ Infectious Diseases 8: 33.

28. Akhtar S, Luby SP, Rahbar MH \& Azam I (2001). HIV/AIDS knowledge, attitudes and beliefs based predication models for practices in prison inmates, Sindh, Pakistan. Southeast Asian J Trop Med public Health 32: 351-61.

29. Sheikh NS, Sheikh AS \& Shan RU (2003). HIV/AIDS; Knowledge, attitude, behavior and practices in Prisoners. Prof Med J 10: 279-289.

30. Ahmed S, Mehmood J, Awan AB, Zafar ST, Khoshnood K \& Khan AA (2009). Female spouses of IDUs in Pakistan: A ridge population of the HIV epidemic. EMHJ 17: 271-6. 